\title{
Utilization of ICT Tools by the Extension Personnel for Effective Delivery of Farm Information
}

\author{
M.Kavaskar, A.Sharmila
}

\begin{abstract}
In India about 760 millions of farmers are engaged in agriculture. According to an estimate more than 60 per cent of the farmers have no access to any source of modern agriculture information. Reaching to these unreached farmers is a great big challenge before the extension system. Now times $21^{\text {st }}$ century declared to be the age of information and communication technology. This is the time when more people everywhere are involved in acquiring new knowledge and skills. The need of ICT interventions are felt need of the hour in agriculture. Thus, it can be said that the twenty first century, it is necessary to use advanced communication media for rural and agricultural development in its proper perspective of message dissemination and feedback along with people's participation and contribution so as to meet the felt needs of people living under diverse socio-economic conditions and here an extension agent should act as a catalyst for transfer of farm technologies. Hence, a present study was taken to assess the utilization pattern of ICT tools among extension personnel. The present study was conducted in Cuddalore District of Tamil Nadu. The 120 extension personnel working in the state department of agriculture were selected as sample for the study by simple random sampling method. The Data were collected through well structured questionnaire. Careful analysis, tabulation and classification of data were done. Mean, frequency, percentage were employed for the interpretation of results. The results showed that majority $(70.83$ per cent) of the extension personnel were utilized the internet / web services for gaining knowledge followed by (41.67 per cent) of the extension personnel were utilized agriportals for transfer of technology.
\end{abstract}

Keywords: Purpose utilization, preference of Utilization, ICT tools, Extension personnel.

\section{INTRODUCTION}

Indian agriculture is dominated by small and marginal farmers whose education is weak and majority of are often unable to access information that could increase yield for their crop. The government has a huge research and development infrastructure in the form of institutions such as the Indian Council of Agricultural Research (ICAR), Agricultural Universities and Krishi Vigyan Kendra's (KVKs) and other institutes, but today these institutions are facing many constraints in mobility of technological staffs for transfer of technological information at the village level.

Manuscript published on 30 September 2019.

*Correspondence Author(s)

M.Kavaskar*, Dept. of Agrl.Extension, Faculty of Agriculture, Annamalai University, Chidambaram, Tamil Nadu.

A.Sharmila, Dept. of Agrl.Extension, Faculty of Agriculture, Annamalai University, Chidambaram,Tamil Nadu.

(C) The Authors. Published by Blue Eyes Intelligence Engineering and Sciences Publication (BEIESP). This is an open access article under the CC-BY-NC-ND license http://creativecommons.org/licenses/by-nc-nd/4.0/
There has been no significant technology innovation, which could give a fresh impetus to agricultural productivity. Insufficient extension services and poor access to information further widen the gap in the adoption of technology and lead to poor productivity levels; in fact information is critical to the social and economic activities that comprise the development process and right information at right time will play a crucial role for development of Indian agriculture. Here comes the role of ICTs, which are powerful and productive with new ideas, methods of the technology dissemination and further improving the knowledge and information among there society. The present are is right termed as an information era. Therefore, information and wide access to ICTs is considered as wealth. People want adequate and authentic information as early as possible. In recent years, there is visible shift from the old ways to the modern ways of information delivery system. (ICT) has become a powerful tool for improving the delivery service and enhancing local development opportunities (Gorstein, 2003). Information and Communication Technology (ICT) is a global term that includes all technologies for the manipulation and communication of information. ICTs are defined as electronic and digital technologies for storing, processing, transferring of information and communication. These are enabling technologies that allow quicker and more efficient exchange and processing of information. During the last two decades, remarkable developments have taken place in information and communication technology. The ICT tools like desktop and laptop computers, tablet PCs, cell phones, smart phones, satellite phone, FM radio; multimedia devices like web camera, digital camera, handy cam, data cards, blue-tooth; storage devices like pen drive, CD-ROMs and DVDs; information kiosks, touch screen systems, experts systems etc. have been popular for information exchange. Computer and Internet enabled technologies like e-mail, e-commerce, e-learning, e-conferencing, Interactive voice response services (IVRS), various type call centers, teleconferencing, video conferencing, computer assessed services, wireless application protocol (WAP) and other online services; mobile enabled services like SMS, MMS, GPRS, web based GIS, remote sensing etc. has been generalized among the people. It is essential to effectively communicate the useful agricultural technologies to the farmers. Improved communication and access to agriculture information are directly related to empowerment of farming community (Kavaskar et al., 2016).Application of these ICT tools and techniques in agriculture should be increased. ICT must be used to reach small and marginal farmers, who are the vast majority of Indian farmers and often unable to access agriculture

(Mahalingam, 2001).

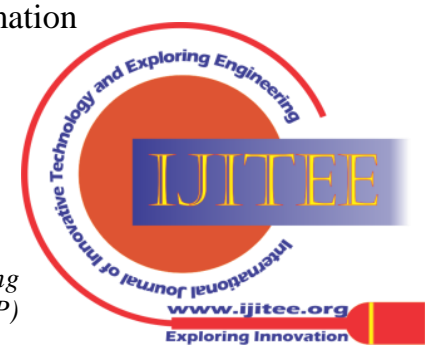


ICTs have played important role in developing countries. ICTs can provide easy access to local or global information, knowledge and are simple channels for two-way communication (Sharmila and Kavaskar, 2017). In this regard a present research study was taken to assess the utilization pattern of ICT tools among extension personnel of state department of agriculture in Tamil Nadu.

\section{METHODOLOGY}

The present research study was taken to assess the utilization pattern of ICT tools among extension personnel among the State Department of Agriculture in Tamil Nadu. The present study was conducted in Cuddalore District of Tamil Nadu. The 120 extension personnel working in the state department of agriculture were selected as sample for the study by using simple random sampling method. The Data were collected through a well structured questionnaire. Careful analysis, tabulation and classification of data were done. Mean, frequency, percentage were employed for the interpretation of results.

\section{Purpose of utilization of ICT tools}

The purpose of utilization of ICT tools were classified based upon their purpose of utilization by extension personnel viz., for gaining knowledge/ recall information, for transfer of technology, for training/ teaching, for making/ sending reports and for data analysis. Based on the response a score of 1 to 5 was given.

\section{Preference of utilization}

The preference of utilization of ICT tools by the extension personnel. The preference are divided into five categories like clarity, easy to operate, need based, effective and attractive. Based on the response a score of 1 to 5 was given.

\section{RESULTS AND DISCUSSION}

\section{Purpose of utilization of ICT tools}

To find out the purpose of utilization of ICT tools were categorized based upon their purpose of utilization by extension personnel viz., for gaining knowledge/ recall information, for transfer of technology, for training/ teaching, for making/ sending reports and for data analysis. The collected data are presented in Table 1.

Table 1. Distribution of extension personnel according to their purpose of utilization of ICT tools

\begin{tabular}{|c|c|c|c|c|c|c|c|c|c|c|c|}
\hline \multirow{3}{*}{$\begin{array}{l}\text { S. } \\
\text { No }\end{array}$} & \multirow{3}{*}{ ICT tools } & \multicolumn{10}{|c|}{ Purpose of utilization } \\
\hline & & \multicolumn{2}{|c|}{$\begin{array}{c}\text { For gaining } \\
\text { knowledge/recent } \\
\text { information }\end{array}$} & \multicolumn{2}{|c|}{$\begin{array}{c}\text { For transfer of } \\
\text { technology }\end{array}$} & \multicolumn{2}{|c|}{$\begin{array}{l}\text { For training/ } \\
\text { teaching }\end{array}$} & \multicolumn{2}{|c|}{$\begin{array}{c}\text { For } \\
\text { making/sending } \\
\text { reports } \\
\end{array}$} & \multicolumn{2}{|c|}{ For data analysis } \\
\hline & & No. & Per cent & No. & Per cent & No. & Per cent & No. & Per cent & No. & Per cent \\
\hline 1. & MS Word & - & - & 05 & 4.17 & 08 & 6.67 & 107 & 89.17 & - & - \\
\hline 2. & MS Excel & - & - & - & - & - & - & - & - & 86 & 71.67 \\
\hline 3. & MS Power point & - & - & 11 & 9.17 & 81 & 67.50 & - & - & - & - \\
\hline 4. & Internet/ web services & 85 & 70.83 & 14 & 11.67 & 27 & 16.67 & 04 & 3.33 & - & - \\
\hline 5. & SPSS & - & - & - & - & - & - & - & - & 08 & 6.67 \\
\hline 6. & MMT & 24 & 20.00 & 16 & 13.33 & - & - & 06 & 5.00 & - & - \\
\hline 7. & GIS & 30 & 25.00 & 08 & 6.67 & 12 & 10.00 & 03 & 2.50 & - & - \\
\hline 8. & $\begin{array}{l}\text { Web based search } \\
\text { engines }\end{array}$ & 61 & 50.83 & 18 & 15.00 & 39 & 32.50 & - & - & - & - \\
\hline 9. & Agriportals & 09 & 7.50 & 50 & 41.67 & 26 & 21.67 & - & - & - & - \\
\hline 10. & IMCD & - & - & 48 & 40.00 & - & - & 04 & 3.83 & - & - \\
\hline 11. & DSS & 18 & 15.00 & 15 & 12.50 & - & - & - & - & - & - \\
\hline 12. & Expert system & 27 & 22.50 & 44 & 36.67 & 20 & 16.67 & - & - & - & - \\
\hline 13. & Social networks & 29 & 24.17 & 31 & 25.83 & 15 & 12.50 & 45 & 37.50 & - & - \\
\hline 14. & FCMS & 03 & 2.50 & 47 & 39.17 & 33 & 27.50 & 27 & 22.50 & - & - \\
\hline 15 & Digital camera & - & - & 20 & 16.67 & 15 & 12.50 & 75 & 62.50 & - & - \\
\hline
\end{tabular}

The data shown in Table 1 revealed that majority (70.83 per cent) of the extension personnel were utilized the internet / web services for gaining knowledge followed by the web based search engine (50.83 per cent), geographical information system (GIS) (25.00 per cent), social networks (24.17 per cent), expert system (22.50 per cent), mobile map technology (MMT) (20.00 per cent), decision support system (DSS) (15.00 per cent), agriportals (7.50per cent) and farm crop management system (FCMS) (2.50 per cent). More than two-fifth (41.67 per cent) of the extension personnel were utilized agriportals for transfer of technology followed by interactive multimedia compact disc (IMCD) (40.00 per cent), farm crop management system (FCMS) (39.17 per cent), expert system (36.67 per cent), social networks (25.83 per cent), digital camera (16.67 per cent), web based search engine (15.00 per cent), mobile map technology(MMT) (13.33 per cent), decision support system (DSS) (12.50 per cent), internet/ web services (11.67 per cent).
Only meagre percentage of the extension personnel utilized ICT tools namely MS power point (9.17 per cent) followed by geographical information system (GIS) (6.67 per cent) and MS word (4.17 per cent) for the purpose of transfer of technology.More than half $(67.50$ per cent $)$ of the respondents utilized MS power point for teaching and training followed by web based search engine (32.50 per cent), farm crop management systems (FCMS) (27.50 per cent), agriportals (21.67 per cent), internet web services (16.67 per cent), social networks (12.50 per cent). Only meagre percentage of the extension personnel utilized ICT tools viz., geographical information system (GIS) (10.00 per cent) and MS word (6.67 per cent).

Published By:

Blue Eyes Intelligence Engineering and Sciences Publication (BEIESP)

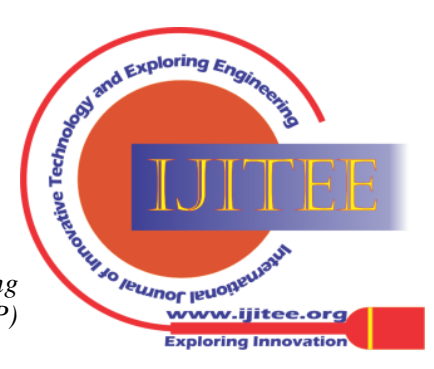


Most of the respondents (89.17 per cent) were utilized MS word for making/sending reports followed by digital camera (62.50 per cent), social networks (37.50 per cent), and farm crop management system (FCMS) (22.50 per cent). Only meagre percentage of the extension personnel utilized ICT tools namely mobile map technology (MMT) (5.00 per cent), inter active multimedia compact disc (IMCD) (3.33 per cent), internet/web services ( 3.33 per cent) and geographical information system (GIS) (2.5 per cent). For data analysis the tools namely SPSS and MS excel was utilized by ( 6.67 per cent and 71.67 per cent).

Hence, it could be concluded that most of the extension personnel utilized the ICT tools for making/sending reports followed by gaining knowledge, for transfer of technology, teaching and training, and data analysis. The probable reason might be that internet has its wide application in the field of transfer of technology. In case of extension, internet helps the extension personnel to access unlimited information and expose to wider spectrum of ideas and concepts. Manual search is laborious and time consuming whereas online search made retrieval of information is easy and indeed. Internet is a rich professional resource for the extension personnel involved in the process of educating the farming community. This finding is support with the findings of (Okafor and Okwuchukwv, 2015).

\section{Preference of utilization of ICT tools}

This part highlights the preference of utilization of ICT tools by the extension personnel. The preference are divided into five categories like clarity, easy to operate, need based, effective and attractive. The data are collected in these aspects and results are presented in Table 2 .

Table 2. Distribution of extension personnel according their preference of utilization of ICT tools

$(n=120)^{*}$

\begin{tabular}{|c|c|c|c|c|c|c|c|c|c|c|c|}
\hline \multirow{2}{*}{$\begin{array}{c}\text { S. } \\
\text { No }\end{array}$} & \multirow{2}{*}{ ICT tools } & \multicolumn{2}{|c|}{ Clarity } & \multicolumn{2}{|c|}{ Easy to operate } & \multicolumn{2}{|c|}{ Need based } & \multicolumn{2}{|c|}{ Effective } & \multicolumn{2}{|c|}{ Attractive } \\
\hline & & No & Per cent & No & Per cent & No & Per cent & No & Per cent & No & Per cent \\
\hline 1. & MS Word & 13 & 10.83 & 17 & 14.17 & 79 & 65.83 & 18 & 15.00 & 15 & 12.5 \\
\hline 2. & MS Excel & 19 & 15.83 & 05 & 4.17 & 39 & 32.50 & 23 & 19.17 & - & - \\
\hline 3. & MS Power point & 18 & 15.00 & 03 & 2.50 & 54 & 45.00 & 17 & 14.17 & - & - \\
\hline 4. & Internet/ web services & - & - & 20 & 16.67 & 63 & 52.50 & 30 & 25.00 & - & - \\
\hline 5. & Analytic package SPSS & - & - & - & - & 07 & 5.83 & 01 & 0.83 & - & - \\
\hline 6. & MMT & 09 & 7.50 & 04 & 3.33 & 27 & 22.50 & 04 & 3.33 & - & - \\
\hline 7. & GIS & 12 & 10.00 & - & - & 33 & 27.50 & 08 & 6.67 & - & - \\
\hline 8. & Web based search engines & 13 & 10.83 & 24 & 20.00 & 58 & 48.30 & 10 & 8.33 & 13 & 10.83 \\
\hline 9. & Agriportals & 17 & 14.17 & 20 & 5.83 & 49 & 40.83 & 01 & 0.83 & 04 & 3.33 \\
\hline 10. & IMCD & - & - & 07 & 4.17 & 35 & 29.17 & 10 & 8.33 & - & - \\
\hline 11. & DSS & - & - & 05 & 4.17 & 24 & 20.00 & 04 & 3.33 & - & - \\
\hline 12. & Expert system & 14 & 11.67 & 29 & 24.17 & 38 & 31.67 & 04 & 3.33 & 06 & 5.00 \\
\hline 13. & Social network & 19 & 15.83 & 10 & 8.33 & 57 & 47.50 & 21 & 17.50 & 13 & 10.83 \\
\hline 14. & FCMS & 07 & 5.83 & 14 & 11.67 & 45 & 37.50 & 27 & 22.50 & 19 & 15.83 \\
\hline 15. & Digital camera & 55 & 45.83 & 12 & 10.00 & 33 & 27.50 & 06 & 5.00 & 04 & 3.33 \\
\hline
\end{tabular}

It could be observed from the Table 2 indicate the preference of utilization of the ICT tools by the extension personnel the preference of MS word was more due to need based (65.83 per cent) followed by effective ( 15.00 per cent), easy to operate (14.17 per cent) attractive (12.50 per cent) and clarity (10.83 per cent). Whereas MS excel highly used by them due to need based (32.50 per cent) followed by effective (19.17 per cent), clarity (15.83 per cent) and easy to operate (4.17 per cent). The need based preference of the tool like MS Power point (45.00 per cent) followed by clarity (15.00 per cent), effective (14.17 per cent) and easy to operate ( 2.50 per cent). Majority of the extension personnel ( 52.50 per cent) for need based utilize the ICT tool followed by effective (25.00 per cent) and easy to operate (16.67 per cent).

A meager percentage (5.83 per cent) of the extension personnel utilized the ICT tool like analytic package SPSS for its need based and effective ( 0.83 per cent). The tools mobile map technology (MMT), geographical information system (GIS) were utilized by a less number of extension personnel for need based (22.50 per cent and 27.50 per cent), clarity (7.50 per cent and 10.00 per cent), effective (3.33 per cent and 6.67 per cent) and easy to operate (3.33 per cent).

The need based preference of the tool like web based search engines (48.30 per cent) followed by easy to operate (20.00 per cent) a same percentage of the extension personnel as clarity and attractive (10.83 per cent), effective

(8.33 per cent).The preference of utilization of the ICT tools by the extension personnel the preference of agriportals was due to need based (40.83 per cent) followed by easy to operate (16.67 per cent), clarity (14.17 per cent), attractive (3.33 per cent) and effective ( 0.83 per cent).

The tools, interactive multimedia compact disc (IMCD) and decision support system (DSS) were utilized by the extension personnel for their easy to operate (5.83 per cent and 4.17 per cent), need based (29.17 per cent and 20.00 per cent), effective ( 8.33 per cent and 3.33 per cent).

The tools expert system, social networks were utilized by the extension personnel for clarity (11.67 per cent and 15.83 per cent),

easy to operate ( 24.17 per cent and 8.33 per cent), need based (31.67 per cent and 47.50 per cent), effective (3.33 per cent and 17.50 per cent) and attractive (5.00 per cent and 10.83 per cent). The tools, farm crop management system (FCMS) and digital camera were utilized by the extension personnel for clarity (5.83 per cent and 45.83 per cent), easy to operate (11.67 per cent and (10.00 per cent), d based (37.50 per cent and 27.50 per cent), effective (22.50 per cent and 5.00 per cent) and attractive (15.83 per cent and 3.33 per cent).

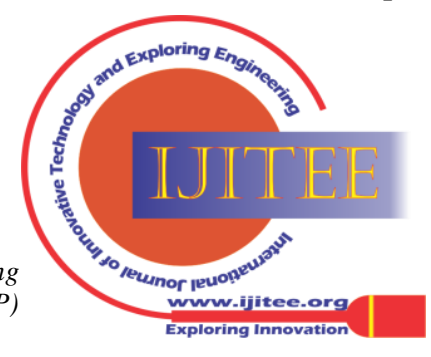


Hence, it could be concluded that majority of the extension personnel the preference of utilization was need based, clarity, effective, easy to operate and attractive. The reason behind this might that internet and other ICT tools have brought about a revolution of a different kind. This finding derives support from the findings of (Smaranika, 2010).

\section{CONCLUSION}

Most of the extension personnel utilized the ICT tools for making/sending reports for MS word (89.17 per cent) followed by gaining knowledge for internet/ web services (70.83 per cent) and transfer of technology through agriportals (41.67 per cent). The preference of MS word was more due to need based (65.83 per cent), digital camera was more due to clarity (45.83 per cent). Most of the extension personnel faced general constraints like., lack of training and skill development followed by lack of latest ICT infrastructure, high cost of ICTs and internet connection is poor/low. Majority of the extension personnel suggested that the selection of ICTs tool should be proper, location specific and need based followed by available ICTs should be in workable conditions and feasibility of the ICTs should be tested.

\section{REFERENCES}

1. Gorstein, M. (2003). Effective Use: A Commonly Informatics Strategy Beyond the Digital Divide. Pakistan Academy for Rural Development, Peshawar: 259-269.

2. Kavaskar,M ., Santha Govind and S. Mariappan.(2016). Suggestions for Effective Utilization of Interactive Multi Media Compact Disc (IMCD) - As a Tool for Transfer of Technology, Progressive Research - An International Journal 11 (5) : 3446-3449

3. Mahalingam, N. (2001). Prosperity through Agriculture, Kisan World, 28 (9): $3-4$

4. Okafor Godson and Okwuchukwv. (2015). Access to and Pattern of ICT Use Among Undergraduate Students of Nnamdi Azikiwe University, International Journal of Nigeria Humanities and Social Science $6(4): 1-11$

5. Sharmila. A and M.Kavaskar. (2017). Knowledge Level of Extension Personnel on Information and communication Technology (ICT), Journal of Global Communication 10 (2):91-95.

6. Smaranika Parida. (2010). 'Utilization of Information and Communication Technology (ICT) Tools by Staff and Students in Universities, M.Sc (Ag.,) Thesis, University of Agricultural Sciences, Dharward, Karnataka. 